\title{
Sztuka i dobór naturalny
}

KEY WORDS

art, natural selection, Darwin, evolutionism

\begin{abstract}
Dutton Denis, Sztuka i dobór naturalny [Art and Natural Selection]. Kultura - Społeczeństwo - Edukacja nr 2(8) 2015, Poznań 2015, pp. 163-181, Adam Mickiewicz University Press. ISBN 978-83-2323004-5. ISSN 2300-0422

The relation between art and the idea of natural selection makes the key issue of this paper. The author examines how Charles Darwin's concept of evolution might have affected the sphere of aesthetics. However, the author arguments against understanding of art as a side product of human progress and takes it as an independent form of human agency. The critique of various evolutionary standpoints laid out in this article holds to the standpoint that we cannot recreate with other means the moments of pleasure delivered by art. Thus it is extremely important to understand art as a form of human creativity and a necessary part of our existence beyond biological determinism stressed out by many evolutionary thinkers.
\end{abstract}

Karol Darwin nie był pierwszym myślicielem, który sugerował, że żywe organizmy ewoluowały w czasie. Przedsokratejski filozof Anaksymander wysunął podobne twierdzenie już dwa i pół tysiąca lat temu. Jego koncepcja stała się powszechnie akceptowaną w czasach Darwina. Również Darwin nie był pierwszym, który wysunął hipotezę o współzależności życia zwierząt oraz ich współpracy w celu przetrwania: za jego czasów podobne fakty były nieustannie przywoływane przez teologów jako dowód na istnienie Bożej ingerencji w naturę. Darwinowska teoria ewolucji wygrała, ponieważ zakładała istnienie fizycznego mechanizmu, który tłumaczył w sposób racjonalny ewolucję gatunków: rozwój gatunków w procesie przypadkowych mutacji i przetrwania selektywnego, określanych już potem zawsze jako dobór naturalny. 
W jednej chwili teoria doboru naturalnego pozbawiła naturalizm religijny jego podstawowego uzasadnienia. Darwin odkrył czysto fizyczny proces, który kształtuje organizmy, jakby były celowo zaprojektowane. W gruncie rzeczy były „zaprojektowane”, ale w innym kontekście: ewolucja jako proces całkowicie przypadkowy, a nie - świadomy i zamierzony. Współcześnie biblijni kreacjoniści nadal przekonują o istnieniu Bożej interwencji w przynajmniej niektórych elementach świata przyrody, na przykład w zawiłym sposobie tkania gniazd przez ptaki lub skomplikowanej budowie ludzkiego oka. Każdy, kto zna zasady ewolucji, łatwo wskaże błędy w poglądach kreacjonistów. Jednak jeśli chodzi o odniesienie ewolucji do kulturowego i artystycznego aspektu (najistotniejsze przykłady racjonalnego i celowego planowania i działania czlowieka), zagadnienia o stworzeniu i przeznaczeniu pojawiają się znowu w sposób nie w pełni akceptowany nawet przez świadomych obrońców darwinizmu. Jedną rzeczą jest powiązanie między strukturą i funkcją systemu odpornościowego, czy budową ucha środkowego a zasadami działania ewolucji. Zupełnie czym innym jest jednak tłumaczenie, że ewolucja miała wpływ na dzieła Albrechta Dürera lub poezję Gerarda de Nervala. Darwin wierzył, że ewolucja wpływa na sztukę tworzoną przez człowieka. W niniejszym tekście chcę zbadać bardzo ważne zagadnienie: czy sztuka w swojej różnorodnej formie jest adaptacją, która rządzi się własnymi regułami, czy istnieje ona bardziej jako nowoczesny efekt uboczny adaptacji?

Psychologia ewolucyjna zajmuje się historią rozwoju oraz adaptacyjnymi funkcjami umysłu i sposobami, w jaki funkcje te kształtują produkty kulturowe umysłu. Oferuje nadzieję na zrozumienie, jak to ujmuje Steven Pinker, „do czego jest przeznaczony lub czemu służy ludzki umysł" - jego cech indywidualnych, uprzedzeń, możliwości - „nie w jakimś mistycznym czy teologicznym sensie, ale w znaczeniu ujawniania reguł „inżynierii”, które rządzą światem przyrody” (Pinker, 2005: 83) Słowo „inżynieria” oznacza tu dążenie do przetrwania i reprodukcji i nie może być rozumiane jako nakierowane na poprawę jakości życia organizmów. Ten fundamentalny fakt poważnie ogranicza zakres tłumaczenia ewolucji. Pinker widzi następująco:

Biologia ewolucyjna wyklucza, na przykład, adaptacje, które mają na celu zapewnienie dobra gatunku, harmonizacji ekosystemu, piękna dla niego samego, korzyści dla osobników innych niż replikatorzy, którzy się adaptują (na przykład konie, które ewolucyjnie wytworzyły siodła), złożoność funkcjonalna bez korzyści reprodukcyjnych (np. możliwość wyliczenia wszystkich cyfr liczby pi) oraz anachronicznej adaptacji organizmów do innych warunków bytowania niż te, w których wyewoluowały (np. wrodzona umiejętność czytania lub wrodzona znajomość gaźnika, czy puzonu). (Pinker, 2005a: XIV) 
Innymi słowy, ewolucyjne wytłumaczenie określonego zjawiska biologicznego czy umysłowego nie może być dokonane poprzez odwołanie się do pozornych korzyści uzyskiwanych dzięki temu aspektowi przez osobniki, społeczeństwo czy czlowieczeństwo jako całość.

Sztuka jest ogólnie akceptowanym i pożądanym dobrem dającym nam dobre samopoczucie. Pozwala nam zajrzeć w głąb ludzkiej duszy, pomóc w szybszym dochodzeniu do zdrowia lub bardziej docenić świat natury. Może sprzyjać tworzeniu się społeczności lub przeciwnie, pokazać zalety kultywowania indywidualności. Sztuka może pocieszyć w czasie kryzysów życiowych, może ukoić nerwy, pomóc w psychologicznym oczyszczeniu, wyzwalać emocje, które oczyszczają umysł i karmią duszę. Nawet jeśli wszystkie te stwierdzenia są prawdziwe, jako takie nie potwierdzają darwinowskiego tłumaczenia sztuki, aż do momentu, gdy wykażemy ich związek ze zdolnością przetrwania i reprodukcją. Problem stanowi pokusa popadania w ciepłe uczucia do sztuki, a co za tym idzie, popełnienia klasycznego błędu logicznego: „Przystosowania ewolucyjne są dobre dla istnienia naszego gatunku. Sztuka jest dobra dla istnienia naszego gatunku. Dlatego sztuka jest adaptacją ewolucyjną".

Błąd! Antybiotyki i klimatyzacja też nam pomagają, ale, w przeciwieństwie do ludzkiego oka, które też jest nam pomocne, nie są one wynikiem ewolucji. Życie jest pełne wynalazków i udogodnień stworzonych przez nas samych lub wykształconych przez tradycje kulturowe i powstałych dzięki zastosowaniu technologii. Te zalety się nieustannie mnożą i zmieniają. Adaptacje ewolucyjne, mimo że relatywnie małe, są bardzo ważnym elementem na długiej liście rzeczy, którymi możemy się cieszyć i z których czerpiemy korzyści. Adaptacje mogą spowodować ból albo przyjemność, mogą wywoływać emocje i mogą (lub nie) działać na naszą korzyść w dniu dzisiejszym, jednak są one częścią naszej natury i osobowości, ponieważ pomogły w przetrwaniu i reprodukcji w długiej historii gatunku Homo sapiens. Stanowią one solidny, ograniczony zbiór cech, który nie uległ znacznej zmianie od czasów plejstoceńskich sawann. Są źródłem fundamentalnych upodobań i pragnień człowieka, które stanowią punkt wyjścia dla łańcuchów motywacyjnych stanowiących element naszej kultury.

Dlaczego lubimy czekoladki? Po części dlatego, że są słodkie i tłuste. Dlaczego lubimy cukier i tłuszcz? Nie ma oczywistej odpowiedzi na to pytanie. Możemy zastanawiać się nad tym bardzo długo i intensywnie, lecz analiza siebie i swojej duszy na wszelkie sposoby nigdy nie odpowie na pytanie, dlaczego lubimy cukier i tłuszcz. Ewolucja, na szczęście dała nam zdolności i pragnienia, aby pomóc 
nam w przetrwaniu i reprodukcji w zamierzchłych czasach. Ewolucja jednak nie daje odpowiedzi na pytanie, dlaczego je posiadamy.

\section{II}

Czekolada nie jest jedynym dostarczycielem sacharozy, fruktozy i związków lipidowych. Jest ona jednak powszechnie dostępna, stanowi element naszej kultury i nie służy jedynie do zaspokajania głodu, ale również jest dobrym produktem na prezent, wyznanie miłości oraz na tworzenie pewnego rodzaju sztuki. Posługując się klasyczną terminologią psychologii ewolucyjnej, można stwierdzić, że chęć spożywania słodyczy jest bezpośrednią przyczyną, a genetycznie wyewoluowana potrzeba odżywiania się cukrami i tłuszczem to przyczyna podstawowa. Chociaż jest to wystarczająco dokładna, psychologiczna definicja odżywiania się, zastosowanie takiego tłumaczenia w naukach społecznych i kulturowych rodzi inne skomplikowane zagadnienia. Cukier i tłuszcz są rodzajem ewolucyjnej przyczyny podstawowej i pomagają wytłumaczyć rolę czekolady w świecie współczesnym, jednak w tym przypadku nie tłumaczą wszystkich powodów powstania tego rodzaju produktów. Możliwe, że wpływ na powstanie czekolady może mieć inna przyczyna podstawowa, na przykład hojność lub spontaniczna chęć obdarowania kogoś miłym prezentem, chęć zdobycia specjalnych zdolności tworzenia czekoladek czy cieszenia się lubianym pożywieniem. Konwencjonalnym podejściem do tego rodzaju zagadnień przez połowę minionego stulecia było traktowanie pragnienia cukru i tłuszczu jako podstawowej biologicznej przyczyny powstania czekolady, a wszystkich innych wymienionych przyczyn jako kulturowej „nakładki” na zapotrzebowanie biologiczne. Podejście darwinowskie jest inne: może istnieć cały szereg wrodzonych instynktów - na przykład instynkty dawania prezentów czy pokazywania swoich umiejętności - które mają korzenie ewolucyjne. Powstałe na drodze ewolucji wzorce zachowań będą podlegały formowaniu i modyfikowaniu kulturowemu. Mogą stać się częścią wrodzonych zasobów tak samo jak pociąg do słodyczy i tłuszczu. Jeśli od czekoladek powrócimy do dziedziny sztuki, od której zaczęliśmy ten wywód, napotkamy znacznie szerszą gamę psychologicznych adaptacji i kulturowych tradycji, które tworzą świat sztuki.

W celu lepszego zrozumienia, w jaki sposób wrodzone instynkty wpływają na świat kultury i tradycji, przejdę do kolejnego, silnie zakorzenionego i powszechnego instynktu, jakim jest unikanie kazirodztwa. W tym przypadku przy- 
czyna (dążenie do jak największego wymieszania się genów i unikania powielania się DNA) jest daleka od bezpośredniej przyczyny, czyli braku zainteresowania i akceptacji pomysłu utrzymywania stosunków seksualnych z bliskimi krewnymi. Instynkt ten pierwszy raz był systematycznie opisywany przez Edwarda A. Westermarcka, dziewiętnastowiecznego fińskiego antropologa, którego prace są przedstawiane przez E.O. Wilsona jako wzorcowy przypadek współistnienia instynktu i kultury w zachowaniu społecznym człowieka (Wilson, 1998). Mechanizm działania głodu u człowieka staje się zrozumiały - staramy się sprawić jedzenie przyjemnym. Kontrastując, efekt opisany przez Westermarcka opiera się bardziej na braku głodu czy zainteresowania w seksualnym znaczeniu tych słów. Dotyczy to bliskich powiązań genetycznych, jednak jest jeden skutek uboczny w przypadku ogólnej zasady antropologicznej, głoszącej, że dzieci w przedziale wieku od trzech do sześciu lat, które przebywają ze sobą, bez względu na pokrewieństwo nie są zainteresowane wspólnym pożyciem seksualnym w późniejszym okresie. Fakt ten został potwierdzony przez badania w izraelskich kibucach: wśród osób, które dojrzewały ze sobą od najwcześniejszych lat, był bardzo niski odsetek małżeństw. W Chinach, gdzie posyłano dziewczynki w bardzo młodym wieku do domu przypisywanego im męża (najczęściej chłopca w podobnym wieku), małżeństwa były często nieudane. Zupełnie inaczej niż w przypadku tej samej praktyki w wieku dojrzewania lub dorosłym. Wilson napisał, że efekt Westermarcka skłania ludzi do nieświadomego wyznania: „Nie będę seksualnie pożądał osób, z którymi miałem bliski kontakt podczas najmłodszych lat mojego życia".

Unikanie kazirodztwa jest typowe nie tylko dla człowieka. U zwierząt, których młode, podobnie jak u Homo sapiens, rozmnażają się na bazie płciowości, w tym u wszystkich innych naczelnych, osobniki często rozpraszają się po osiągnięciu dojrzałości płciowej. W przypadku ludzi związkom kazirodczym dodatkowo zapobiega bagaż kulturowy. Z wyjątkiem bardzo niewielu kultur unikanie kazirodztwa jest tłumaczone, opracowywane, usprawiedliwiane i narzucane przez mitologię, opowieści ludowe, prawo lub przesądy: staje się to pewnego rodzaju tabu. Takie tłumaczenia może racjonalizować efekt Westermarcka, jednak wywodzą się one z zupełnie innego źródła - faktu, że ludzie czasami mogą bezpośrednio zaobserwować, do czego prowadzi kazirodztwo: powoduje większą częstotliwość występowania różnego rodzaju deformacji, w tym karłowatość i niedorozwój umysłowy, jak również wczesną umieralność. W pewnym badaniu sześćdziesięciu społeczności, które nie znają pisma, około jedna trzecia była 
świadoma, że deformacje są wynikiem kazirodczych związków. Nie we wszystkich niepiśmiennych kulturach ludzie pokazują taką świadomość, przypuszczalnie dlatego, że przeciwwskazania dotyczące kazirodztwa były na tyle skuteczne, że nie mieli oni możliwości zaobserwowania niekorzystnych zmian poprzez porównanie ze związkami tradycyjnymi. Inne społeczności, na ogół te, które posługują się pismem oraz mają formalny system prawny, mogą skodyfikować zakaz kazirodztwa i wyraźnie go uzasadnić.

Pojawia się tutaj złożone zagadnienie wrodzoności, dziedzicznej dyspozycji (efekt Westermarcka), formalnego wyrażenia, przez wiele odmiennych kultur, zasad i zagrożeń (tabu kazirodztwa), które mogą być empirycznie zgodne z zaobserwowanymi wynikami (zdeformowane dzieci). Wilson nazywa to „ulepszeniami", które pomagają uniknąć kazirodztwa, sprawiają one wrażenie nieświadomego usprawiedliwiania instynktownych impulsów. Jednak tematy tabu w niektórych przypadkach mogą być bardzo racjonalne: przez bezpośrednio zaobserwowane przypadki śmierci potomstwa związków kazirodczych. Próbuje się tego uniknąć, sprowadzając do tabu, przesądu czy mitologii nadprzyrodzone teorie kazirodztwa. Innymi słowy, temat tabu może się wywodzić z bardzo racjonalnej znajomości powodów rodzenia się zdeformowanych dzieci. A więc mamy: oddziaływanie podświadomości, wrodzone popędy, preferencje i możliwości $z$ jednej strony, natomiast zachowanie oparte na racjonalnych obserwacjach, niezależnych pobudkach i wyuczonym zachowaniu, $z$ drugiej. Pomiędzy tymi naturalnymi ograniczeniami ważny wpływ mają kultura i tradycja w połączeniu z odziedziczoną ludzką naturą, ukierunkowaniem, dostosowaniem i przeciwstawianiem się jej.

Czasami przesądy i mitologia nadają znaczenia impulsom, które się z nich wywodzą; w innych przypadkach obserwacje prowadzone na ich temat pomagają w ich wytłumaczeniu. Większość ludzkiego życia toczy się „na wspólnym obszarze", na którym kumulują się instynkty, zwyczaje, autorytety (szamani w plejstocenie, „eksperci” i media w czasach współczesnych) oraz osobiste, racjonalne decyzje oparte na własnym doświadczeniu. Głód i pragnienie, obawa przed wężami (lub przed gniazdami elektrycznymi), seks i reprodukcja, unikanie kazirodztwa, poczucie sprawiedliwości, język, społeczeństwo są przydatnymi kategoriami analitycznymi w życiu codziennym. Istotne jest, aby mieć je na uwadze, opisując źródła ewolucji i wrodzone impulsy, które z kolei działają na takie zjawiska kulturowe, jak sztuka. 
III

Złotą zasadą pozwalającą wytłumaczyć ewolucję jest biologiczne pojęcie adaptacji: dziedziczone fizjologiczne, emocjonalne lub behawioralne cechy, które skutecznie rozwijają się w osobniku, zwiększając szanse na przetrwanie i reprodukcję. Jednak w jaki sposób można opisać relacje pomiędzy adaptacjami i niezliczonymi cechami ludzkiej biologii i życia umysłowego, które nie są adaptacjami? Podążając za klasyczną teorią ewolucji, wszystko, co zostało wytworzone przez proces adaptacyjny, ale nie jest adaptacją, trzeba zaliczyć do dwóch kategorii: jednorazowego, losowego, lub przypadkowego efektu kombinacji genetycznej, który można określić jako mutację, lub przypadkowo powiązanych efektów ubocznych jednej, lub kilku powiązanych adaptacji. Aby mieć możliwość połączenia ewolucji ze sztuką, trzeba skupić się na odwiecznych, trwałych wzorcach ludzkich zainteresowań, zdolności i preferencji. Przypadkowe, losowe mutacje lub ich efekty nie są odpowiedzią; stanowią zależne czynniki sprawcze ewolucji, ale nie są wzorcami cech, które z niej wynikają.

Kategoria skutków ubocznych prawdopodobnie klasyfikuje sztukę najtrafniej. Czy sztuka może być rozumiana jako produkt uboczny adaptacji? Podręcznikowym przykładem niefunkcjonalnego produktu ubocznego wyewoluowanych adaptacji jest biały kolor kości. Szkielety składają się z wapna, które często występuje w przyrodzie, stanowi część diety zwierząt i jest względnie silnym budulcem. Tak się składa, że nierozpuszczalne sole wapnia, będące budulcem kości, są białe; stąd biały kolor kości. Kości muszą być solidne, aby umożliwić przetrwanie, jednak nie ma żadnych przystosowawczych powodów do tego, aby były białe lub jakiegokolwiek innego koloru. Kolor kości jest następstwem ich składu chemicznego; gdyby sole wapna były na przykład różowe, tak samo stałoby się z kośćmi. Innymi przykładami produktów ubocznych są: pępek, właściwie blizna, która sama w sobie nie pełni żadnej funkcji przystosowawczej, oraz męskie sutki, które są produktem ubocznym procesu tworzącego gruczoły sutkowe u kobiet.

Zmieniając temat $\mathrm{z}$ funkcji ewolucji organicznej na psychologiczną, wchodzimy w zagadnienia dzielące domniemane adaptacje od produktów ubocznych, które są tematem długiego, czasami gorącego sporu. Jednym z niepotwierdzonych źródeł, wywołujących różnice zdań jest sam termin "produkt uboczny”. W życiu codziennym "produkt uboczny" oznacza dodatkowy, pomniejszy lub nieistotny produkt powstały w procesie tworzenia czegoś innego, ważniejszego. 
Sama idea produktu ubocznego mówi o czymś, co nie zaczyna istnienia samodzielnie, tylko powstaje przy okazji tworzenia się czegoś innego. Jak przekonać osobę wierzącą lub patriotę, że przekonania religijne czy odczucie patriotyzmu są produktami ubocznymi plejstoceńskich adaptacji? Jak się przekonała Elisabeth Lloyd, publikując (2005) swoje badania na temat orgazmu kobiety, nawet w tematach bliższych czystej psychologii, traktując istotne wpływy - zjawiska istotne w życiu jednostki - jako produkty uboczne można wzbudzać kontrowersje.

Rozpoczynając swoją pracę w latach osiemdziesiątych, Lloyd przeanalizowała dwadzieścia jeden różnych teorii dotyczących orgazmu u kobiet. Ostatecznie doszła do wniosku, że najprawdopodobniejszą była hipoteza Donalda Symonsa z 1979 roku, głosząca, że męski orgazm jest podstawową funkcją reprodukcji, podczas gdy u kobiet, podobnie jak z sutkami u mężczyzn, jest produktem ubocznym, powstałym w fazie embrionalnej, kiedy obie płcie mają jeszcze wspólną fizjologię. W czasie pierwszych ośmiu tygodni rozwoju ludzki embrion rozwija się tak samo dla obu płci, dopiero później wykształca się penis lub łechtaczka. Lloyd dopuszcza możliwość, że bardzo przyjemny męski orgazm jest adaptacją dla reprodukcji. Nie zgadza się jednak, że kobiecy orgazm, który $\mathrm{u}$ wielu kobiet nie zdarza się podczas każdego stosunku płciowego, jest adaptacją, ale efektem ubocznym mechanizmu wytworzonego przez ewolucję dla męskiej przyjemności. Swoją tezę popiera trzydziestoma dwoma badaniami przeprowadzonymi w okresie siedemdziesięciu czterech lat, które wykazują, że mniej niż połowa kobiet regularnie przeżywa orgazm w trakcie stosunku. Odejmując od tego przypadki wspomagania łechtaczki ręczną stymulacją, odsetek staje się jeszcze mniejszy. Feministyczne poświadczenia oraz krytycyzm wobec seksizmu w historii badań nad kobiecym orgazmem, postrzeganej oczyma mężczyzn, nie uchroniły Lloyd przed deszczem ataków, głównie środowisk feministycznych, które oskarżały ją o trywializowanie kobiecych doznań i - pokłosie powstania z żebra Adama - sprowadzanie ich do pochodnych od męskich doznań.

Stephen Jay Gould wsparł Lloyd w jej badaniach na temat żeńskiego orgazmu. Podniósł kwestię na temat tezy produktu ubocznego w jednej ze swoich rozprawek w magazynie „Natural History” w 1997 roku. Gould systematycznie próbował umniejszyć rolę adaptacji w ewolucji, zastępując ją pojęciem produktu ubocznego, stąd jego powiązania z teoriami Elisabeth Lloyd. W rzeczywistości, według dotychczasowych osiągnięć psychologii, Gould całą sferę ludzkiej kultury i doświadczeń zakwalifikował jako produkt uboczny jednej adaptacji: przerośniętego mózgu ludzkiego. Gould jako metaforę dla, jak mawiał - „nieadaptatyw- 
nych konsekwencji ubocznych" adaptacji, używał słowa „pendentyw” (Gould, Lewontin, 2011). Słowo to jest terminem architektonicznym: opisuje trójkątną przestrzeń wewnątrz budynku, gdzie zaokrąglone łuki lub okna sięgają kopuły lub sufitu. Pendentywy są dobrym miejscem na malowidła, mozaiki, czy inne ozdoby. Łukowe okna nie są produktem ubocznym budynków, w których znajduje się pendentyw; przestrzeń nazwana pendentywem jest produktem ubocznym zaprojektowania w budynku łukowych lub zaokrąglonych okien (por. Gould, Lewontin, 2011).

Dla Goulda „pendentyw definiuje główną kategorię ważnych, ewolucyjnych cech, które nie stały się adaptacjami” (Gould, 1997). Przykłady popierające analogię pendentywu pochodzą ze zwierzęcej fizjologii: małże, ślimaki i tyranozaur. Koncepcja pendentywu w ludzkim życiu jednak ma zastosowanie tylko w przypadku produktów ubocznych szczególnego ludzkiego organu - mózgu, który jest nasycony pendentywami. W rzeczywistości „musi być pełen pendentywów, które są istotne dla ludzkiej natury i ważne dla samoświadomości, ale powstały jako nie-adaptacje i dlatego nie znajdują się w zasięgu psychologii ewolucyjnej”. Fenomeny głoszone przez Goulda mogą być przyczyną „większości naszych cech psychicznych i potencjałów" (Gould, 1997). W swoich wypowiedziach używa wielu „może” i „musi”, podczas gdy płynnie opisuje różnorodność pendentywów w ewolucyjnym świecie fizjologii zwierząt, jest jednak irytująco niejasny, kiedy przechodzi do ludzkiego zachowania. W zasadzie, na pytanie, które wzorce zachowań nie są pendentywami, lecz adaptacjami, nie ma odpowiedzi, z wyjątkiem ustępstwa, jakiego się podjął pod koniec swojej kariery, w którym ogłosił, że różnice w skłonnościach mentalnych dwóch płci mogą być adaptacjami. Na pytanie, które z uniwersalnych ludzkich wzorców zachowań są pendentywami, podaje kilka sugestii - jedną z nich było wczesnoholoceńskie wynalezienie pisania i czytania - ale nie przeanalizował żadnego. Gould nie czuje potrzeby udowadniania swoich poglądów na ten temat: „Jestem zadowolony ze stwierdzenia, że ludzki mózg stał się tak duży z powodu selekcji naturalnej i z powodów adaptacyjnych - że jest pewien zbiór czynności, które nasi przodkowie z sawann mogli wykonywać tylko z większymi mózgami”. Pendentywy były tylko „często dokooptowane w późniejszej historii ludzkości do pełnienia dodatkowych ważnych funkcji” (Gould, 1997). Nic nie zostało powiedziane o głównej adaptacji - dużym mózgu, który stworzył wszystkie drugorzędne przejawy; właściwie stanowisko Goulda jako całość sugeruje, że nic na ten temat nie może być napisane. Jego obładowany pendentywami mózg okazuje się w końcu 
behawioralnym i kulturowym odpowiednikiem tabula rasa - tablicy pustych pendentywów, faktycznie niewykorzystanych, ale gotowych do zapisania ich i udekorowania wszelakimi wartościami, zainteresowaniami i zdolnościami, zwracając uwagę na historię i kulturę.

Ta niezwykła, żeby nie powiedzieć bezczelna, wbrew najsłynniejszym darwinistom jego pokolenia, próba zakazania ewolucyjnego tłumaczenia psychologicznych cech, nie mogła zostać poparta faktami, które mógłby znać on lub byłyby znane $w$ dzisiejszych czasach. Zauważyłem, że Gould, jako przykład pendentywu podaje praktyki pisania i czytania, kiedy istnieją one zaledwie od pięciu tysięcy lat. Ale co z cechą, której wyraźnie nie udało mu się wymienić: porozumiewanie się za pomocą mowy? Umiejętność pisania i czytania czerpie z ogólnych zdolności. Mowa nie jest produktem ubocznym dużego mózgu, ale efektywną zdolnością adaptacyjną. Dalece mało prawdopodobne jest stwierdzenie, że nasi przodkowie, żyjący na sawannach, lub gdziekolwiek indziej, wykształcili duże mózgi z wielką wielozadaniową inteligencją i nic innego nie zapisywało wielkiej ilości pustych pendentywów, z których część w odpowiednim czasie została zapisana przez język, który znamy dzisiaj. Byłaby to historia w stylu „po prostu tak".

Według aktualnych ustaleń mowa pojawia się u ludzkich istot tak powszechnie jak gruczoły potowe czy paznokcie jako złożony proces psychiczny, pojawiający się spontanicznie i rozwijający się niezawodnie do dojrzałej kompetencji językowej, wszędzie z tą samą regularnością. Ponadto, język miał oczywistą i decydującą o przetrwaniu wartość w czasach plejstocenu. Międzykulturowe cechy języka są strukturalnie jednolite $\mathrm{w}$ sensie projektu adaptacyjnego; nie są wytłumaczalne ani wrodzone. Nawet czynniki, które ingerują w rozwój języka i psychicznych narzędzi z nim połączonych, takie jak autyzm czy afazja, robią to w uporządkowany i diagnostycznie przewidywalny sposób. Dla Goulda takie wewnętrzne składniki ludzkiego postępowania i doświadczenia mentalnego, jak język, mogły być produktem ubocznym cechy mózgu, która w niewyjaśniony sposób powstała na sawannach dla nieznanych celów, ignorując wszystko, co wiemy na temat języka. Niewyobrażalne jest to, że coś tak złożonego strukturalnie i zdumiewająco funkcjonalnego jak mowa mogło powstać w plejstocenie jako produkt uboczny mózgu, który, zwiększając swoje rozmiary, rozwiązywał inne, językowo niepowiązane problemy.

Antyadaptacjonizm Goulda, jego lekceważące próby minimalizacji lub aktywne zaprzeczanie związkom między psychologią, formami kulturowymi a wy- 
ewoluowanymi zdolnościami, dochodzi do skrajności. Wyobraźmy sobie jego dziwaczne stanowisko jako będące odbiciem stanowiska przeciwstawnego, ale równie skrajnego, a mianowicie hiperadaptacjonizmu, który zakłada, iż istnieją konfiguracje poszczególnych genów tłumaczące powstanie każdej cechy życia umysłowego: geny od komponowania albo podziwiania fug, geny od gry w badmintona, od tańczenia pogo i od skłonności do przesadnej obawy o bagaż w samolocie. Nikt oczywiście, nie uwierzy, że to może składać się na wiarygodną psychologię ewolucyjną. Prawda na temat wyewoluowanej ludzkiej natury leży pośrodku, pomiędzy dwoma ekstremami: antyadaptacjonizmem i hiperadaptacjonizmem.

Przekonujące, wyważone stanowisko zajmuje Steven Pinker w książkach Jak działa umyst (2002) i Tabula rasa (2005). Jako główny zwolennik postrzegania ludzkiej kondycji poprzez analizę psycho-ewolucyjną, oczywiście sprzeciwia się on antyadaptacjonizmowi psychologicznemu Goulda. Jak już wcześniej wspomniałem, Pinker jest również ostrożny w formułowaniu twierdzeń o tym, że niektóre aktywności, takie jak sztuka, muzyka, religia i sny, mogą być adaptacjami, ponieważ są dla nas istotne. $Z$ wyjątkiem fikcyjnej narracji Pinker twierdzi, że sztuka jest raczej bardziej produktem ubocznym adaptacji, niż że „jest adaptacyjna w biologicznym sensie tego słowa”, oznaczającym korzystny wpływ na przetrwanie i reprodukcję w środowisku naszych przodków:

Umysł jest neuronowym komputerem, wyposażonym przez dobór naturalny w kombinatoryczne algorytmy do przyczynowego i probabilistycznego rozumowania o roślinach, zwierzętach, przedmiotach i ludziach. Wprawiają go w ruch stany celowe, które służyły biologicznemu przystosowaniu $\mathrm{w}$ środowisku przodków, takie jak żywność, seks, bezpieczeństwo, rodzicielstwo, przyjaźń status i wiedza. Tego samego zestawu narzędzi można jednak użyć do wypełnienia niedzielnego popołudnia projektem o wątpliwej wartości adaptacyjnej. (Pinker, 2002: 566)

"Tworzenie projektów w niedzielne wieczory" - nieszkodliwe, przyjemne, zabijające czas - jest najlepszą drogą do umniejszania roli sztuki. Jednym z najpopularniejszych stwierdzeń Pinkera jest sugestia, że sztuka jest jak sernik dla mózgu. Sernik, dlatego ze przygotowywane jedzenie jest nowym wynalazkiem: „Lubimy sernik truskawkowy nie dlatego, że wyewoluowaliśmy w sobie taki smak". Tym, co zostało w nas wytworzone drogą ewolucji z czasów przodków, są obwody nerwowe, które dają nam 
autentyczną przyjemność ze słodkiego smaku dojrzałych owoców, kremowego uczucia w ustach, jakie wywołują tłuszcze i oleje z orzechów i mięsa, oraz chłodu świeżej wody. Tort jest pakunkiem sensualnych wstrząsów niepodobnym do niczego w naturalnym świecie, ponieważ jest to wytwór megadawek miłych bodźców, które zestawiliśmy z wyraźnym celem naciskania naszych guzików przyjemności. (Pinker, 2002: 567)

Twierdząc, że „niektóre czynności, które postrzegamy jako bardzo głębokie, nie są adaptacjami, tylko produktami ubocznymi" (Pinker, 2002: 568), Pinker stara się trzymać z daleka od hiperadaptacjonizmu: „błędem jest wymyślanie funkcji dla czynności, którym brak takiej konstrukcji, jedynie dlatego, że chcemy je uszlachetnić przez nadanie im imprimatur biologicznej adaptacyjności" (Pinker, 2002: 568). Jednak problemem nie jest sentymentalna próba uczczenia rzeczy, które lubimy - orkiestra smaków sernika - nadając im rangę adaptacji. Dla darwinowskich estetyków zagadnieniem jest, w jaki sposób autentyczne adaptacje mogą wpływać lub tłumaczyć zdolności i preferencje, nawet w przypadku rzadkich przedsięwzięć. Mając na to wzgląd, myślę, że opisywany przez Pinkera sernik, jako produkt uboczny wyewoluowanego i przypuszczalnie adaptacyjnego smaku z ery plejstocenu, wprowadza w błąd. Lepiej rzec, że sernik bezpośrednio zaspokaja te wszystkie smaki. Pinker określa sernik jako „zmysłową bombę w porównaniu do czegokolwiek występującego w naturze", jednak nie jest on mniej naturalny niż większość innych pokarmów, włączając wiele dostępnych dla naszych przodków, jak na przykład miód, dojrzałe owoce, orzechy czy tłuszcz mastodonta, występujących na przestrzeni osiemdziesięciu tysięcy generacji w plejstocenie. Czy można stwierdzić, że słodkie lub tłuste doznania w górnym paleolicie były produktami ubocznymi smaków wyewoluowanych w paleolicie dolnym? Bardziej sensownym jest stwierdzenie, że plejstoceńskie pożywienie było odpowiednie dla smaków $z$ ery plejstocenu, natomiast sernik, mimo że jest pożywieniem z naszych czasów, odwołuje się do tych samych smaków. Innymi słowy, sernik wcale nie jest produktem ubocznym, lecz jednym z nieskończonej liczby produktów żywieniowych dzisiejszych czasów, które mają na celu zaspokajać dzisiejsze smaki, które wyewoluowały wieki temu.

Swoją moc wyjaśniającą psychologia ewolucyjna zawdzięcza głównie identyfikowaniu adaptacji. Zajmuje się również tłumaczeniem funkcji i charakterystyką każdego trwałego ludzkiego fenomenu, zarówno w odniesieniu do jego części, jak i całości, poprzez łączenie ich z właściwościami adaptacji. Darwinowskie podejście do preferencji żywieniowych (tłuszcz, słodycze, pikantność, smak protein, sól, aromaty owoców itp.) nie powinno traktować poszczególnych punktów 
współczesnego restauracyjnego menu jako produktów ubocznych; pozycje te bezpośrednio zaspokajają pradawne preferencje. Podobnie darwinowscy estetycy nie osiągną mocy wyjaśniającej ani przez dowodzenie, że formy sztuki są adaptacjami, ani poprzez sprowadzanie ich do roli produktów ubocznych, ale pokazując, jak ich istnienie i charakter łączą się z plejstoceńskimi zainteresowaniami, preferencjami i zdolnościami.

Oprócz architektonicznego pendentywu i sernika, jako analogię rozważmy jeszcze jeden ludzki wynalazek: silnik spalinowy. Stosując pomysłowo zasadę inżynierii odwrotnej Pinkera, moglibyśmy łatwo wywnioskować, że celem silnika jest wytwarzanie momentu obrotowego w celu wprawienia kół w ruch. Przy okazji możemy również zauważyć, że silnik produkuje nadmiar ciepła. Mamy prawo traktować to zjawisko jako produkt uboczny, efekt uboczny: jeżeli silnik miałby za zadanie wytwarzać moment obrotowy, nie wytwarzając dodatkowo ciepła, nie zrobiłoby nam to większej różnicy - a nawet byłoby postrzegane jako zaleta, gdyż silniki spalinowe wymagają mechanizmów chłodzących, w większości przypadków są to pompa wody i chłodnica. A zatem czy system chłodzący jest produktem ubocznym silnika? Niezupełnie. Jest natomiast wynalazkiem montowanym wraz $z$ silnikiem spalinowym: funkcjonuje w celu rozpraszania nadmiaru ciepła, w rozumieniu naszej inżynierii odwrotnej jest częścią całego, funkcjonalnie połączonego mechanizmu. Jest nierozłączną częścią silnika tak samo, jak systemy ogrzewające czy chłodzące w ludzkim ciele. Do systemów takich należą chroniące życie homeostatyczne reakcje, jak pocenie się, dreszcze czy gorączka. Są one wewnętrznymi elementami ludzkiego systemu fizjologicznego, nie produktem ubocznym adaptacji - pendentywami lub epifenomenami. Podobnie jak ciało człowieka, silniki spalinowe nie mogą funkcjonować bez odpowiedniego systemu chłodzenia: w analogii silnika systemy chłodzące są adaptacjami.

Pójdźmy z analogiami o krok dalej. Przypuśćmy, że woda użyta do chłodzenia naszego silnika jest przesyłana do innego, mniejszego urządzenia $z$ wentylatorem, służącym do ogrzewania wnętrza, w którym siedzi kierowca i pasażer. Czy można stwierdzić, że ogrzewanie jest produktem ubocznym całego systemu? Po raz kolejny odpowiedź brzmi: nie. Bardziej niż ubocznym epifenomenem, grzejnik jest w całości zaplanowanym sposobem wykorzystania czegoś, co naprawdę stanowi produkt uboczny (nadmiar ciepła wytwarzany przez silnik) dla korzyści kierowcy, zaspokajając jego potrzebę jazdy w ogrzanym aucie. Mobilność samochodów, wymagana przez ludzi, pragnienie ciepła, w żadnym przypadku nie są ani częścią, ani cechą konstrukcyjną, również nie produktem 
ubocznym silnika: tłumaczą one raczej powód istnienia samochodu, z silnikiem i ogrzewaniem. Rzeczony grzejnik, jak każda inna wynaleziona część, która jest dla nas użyteczna, będąc zależną od produktu ubocznego, sama wcale nie musi być $z$ tego powodu produktem ubocznym. Fakt, że silnik wydziela ciepło, sam z siebie jest niewygodny, jednak ludzka pomysłowość potrafi przekształcić to w zaletę (jeśli silniki wydzielałyby światło zamiast ciepła, inżynierowie z całą pewnością umieliby produktywnie wykorzystać tę przypadłość, a do ogrzewania wykorzystaliby inne urządzenie). Prawdą jest, że ludzie nie wynaleźli i nie produkują samochodów w celu stworzenia grzejnika, ale to tak, jakby powiedzieć, że ewolucja nie stworzyła oczu po to, aby móc wykreować powieki. Powieki również są adaptacją (dalej idąc, tworem człowieka służącym do wzmocnienia oczu mogłyby być okulary). Kiedy części całego mechanizmu - artefaktu lub wyewoluowanego systemu - są od siebie funkcjonalnie zależne, sprawą staje się zrozumienie, dlaczego i w jaki sposób maszyny lub organy są ze sobą powiązane oraz jakie zadania realizują.

Badanie takich funkcjonalnych współzależności wymaga czegoś więcej, niż tylko podzielenia cech na dwie kategorie: adaptacje i produkty uboczne. Istotną kwestią jest zbadanie, czym jest sedno adaptacji - ale wtedy także: produktów ubocznych adaptacji, wykorzystań, wzmocnień i rozszerzeń adaptacji, różnych kombinacji rozszerzeń i tak dalej. W tym sensie wyjaśnienia darwinowskie zawsze wracają do przeszłości, do adaptacji, które pochodzą ze środowiska naszych przodków, również poprzez określenie wpływu historii i kultury na to, jak wyewoluowane adaptacje, precyzyjnie zaprojektowane, powstały w ludzkim życiu, jak ulegały modyfikacji, rozwijały się, zwiększały swoją rolę - lub nawet były tłumione. Podając przykład wydzielania przez silnik spalinowy światła zamiast ciepła, chciałem podkreślić przypadkowość występowania zarówno adaptacji, jak i ich produktów ubocznych: tym, prawdę mówiąc, staliśmy się - istotami, które czerpią przyjemność zarówno z jedzenia sernika, jak i ze słuchania Chopina. Jeśli w środowisku naszych przodków warunki byłyby inne, mogliśmy wyewoluować zupełnie inaczej, a co za tym idzie, inaczej myśleć czy odczuwać.

Zależność od prehistorycznych wydarzeń, których nigdy do końca nie poznamy, oraz ówczesnych warunków, o których dziś możemy jedynie spekulować, sprawia, że cała psychologia darwinowska jest zależna nie tylko od ogólnych stwierdzeń teorii ewolucji, ale również od bliskiej, empirycznej obserwacji ludzkiego mózgu i jego funkcji adaptacyjnych dzisiaj, zwracając szczególną uwagę na międzykulturowość. Łącząc wszystkie te czynniki z wiedzą, jaką posiadamy na 
temat grup łowców-zbieraczy, które przetrwały do dzisiaj, dążymy do jak najlepszego zrozumienia ludzkiego umysłu i jego wytworów, od prymitywnych toporów do Szekspirowskich komedii. Tym samym możemy lepiej zrozumieć ograniczenia umysłu: tych dziedzin, w których zawsze działa niedoskonale, $z$ tendencjami do na przykład niepotrzebnych reakcji emocjonalnych lub antyreproduktywnych uprzedzeń. Na tej płaszczyźnie egzamin zdaje teoria inżynierii odwrotnej. Jako człowiek, który rozumie, że ogrzewanie samochodowe czerpie $\mathrm{z}$ nadmiaru ciepła wytwarzanego przez silnik, nie będę oczekiwał natychmiastowego grzania w zimny poranek, więc rozumiejąc pochodzenie ewolucyjne sztuki, mam większą szansę zrozumieć, dlaczego sztuka w naszej historii odgrywa swoją rolę w taki a nie inny sposób.

Pisanie, czytanie, sernik ani Cadillac nie są plejstoceńskimi adaptacjami. Ale nie zrozumiemy w sposób właściwy ich genezy i popularności, ignorując wyewoluowane zainteresowania i zdolności, dzięki którym powstały. Istoty ludzkie czerpią przyjemność z podróżowania, „wolność pustej drogi”; lubimy się komunikować, jesteśmy na ogół wszystkożerni i lubimy słodycze oraz tłuszcz: te czynniki tłumaczą technologie i formy kulturalne z czasów zarówno prehistorycznych, jak i nowoczesnych. Wgłębianiem się w te relacje zajmuje się psychologia ewolucyjna, i w przypadku sztuki, estetyka darwinowska. Jak już wcześniej napomniałem, E.O. Wilson opisuje tabu kazirodztwa nie jako produkt uboczny efektu Westermarcka, ale jako jego ulepszenia i kodyfikacje. Wspomniałem o "rozszerzeniach”. Dobór słownictwa Wilsona jest całkowicie poprawny, podobnie jak dalsze opisy sztuki jako sposobu, w jaki istoty ludzkie czerpią przyjemność przez dostarczanie preferencji poznawczych, które są częścią adaptacji prehistorycznego środowiska, Pinkera. Sernik mówi o wrodzonych preferencjach odczuwania przyjemności, o tym również wspomina Pierścień Nieblunga Wagnera, chociaż na płaszczyźnie kompleksowości emocjonalnej i intelektualnej.

\section{IV}

Bazując na powyższej argumentacji, staję po stronie przeciwników Symonsa, Lloyd i Goulda teorii kobiecego orgazmu, jako nieadaptacyjnego produktu ubocznego adaptacyjnego procesu u mężczyzn. Bezpośrednie związek między kobiecym orgazmem a ciążą, według Lloyd, nie ma miejsca. Korzystając z tego argumentu, w porozumieniu z Gouldem, doszła ona do wniosku, że kobiecy 
orgazm nie jest adaptacją. Moim zdaniem, analiza ta implikuje dosyć marne i ograniczone spojrzenie na ludzką seksualność. W tym sensie, argumenty te są bezpośrednio zbieżne $z$ argumentami na temat tego, czy artystyczne przyjemności mogą być adaptacyjne. Lloyd uważa fakt, że kobiety mogą osiągać orgazm łechtaczkowy samodzielnie, bez udziału partnera, za bardzo istotny. Jednak to samo można powiedzieć o męskich orgazmach - a to zapewne nie podaje w wątpliwość statusu męskiego orgazmu jako adaptacji. Biolog John Alcock podważył teorię Lloyd, argumentując, że kobiecy orgazm nie musi występować w każdym akcie płciowym, żeby być adaptacją, i z całą pewnością ma rację. W rzeczywistości, uzależniając adaptatywność kobiecego orgazmu łechtaczkowego bądź nie, od tego, czy występuje on w każdym stosunku, podajemy również w wątpliwość standardy dotyczące zakończonego ejakulacją męskiego orgazmu - a więc ten rodzaj maskulinistycznego programu, na który Lloyd w innym miejscu pomstuje.

Wyobraźmy sobie na moment szeroki repertuar umysłowej wyobraźni i zmysłowych odczuć kobiety i mężczyzny podczas zabaw erotycznych. Każdy z tych elementów może przyczynić się do przyjemności seksualnej i prawie wszystkie są dziedziczne, występują w określonym procencie w populacji, lecz niekoniecznie w każdym z nas. Dla niektórych kobiet piersi są delikatną strefą erogenną, dla niektórych mężczyzn ich pieszczenie jest bardzo istotne, dla innych nie. Niektóre kobiety doświadczają tak zwanego orgazmu waginalnego, inne lechtaczkowego, niektóre obu, a część nigdy nie szczytowała podczas stosunku. Zwróćmy uwagę na zróżnicowanie pozycji seksualnych, stosunki oralne, a zwłaszcza na całowanie. Chociaż erotyczne pocałunki nie powodują ciąży i nie występują we wszystkich kulturach świata, kto byłby skłonny powiedzieć, że są one jedynie nieadaptacyjnym produktem ubocznym stosunku płciowego? Istnienie erotycznego rytuału spotykania się ludzkich ust jest wyewoluowaną adaptacją. Tylko zubożałe spojrzenie na seks mogłoby nadać cechę adaptacyjności jedynie męskiemu orgazmowi i sugerować, że wszystko inne, co dzieje się podczas seksu, od flirtu, przez grę wstępną, po czułe zakończenie, jest tylko przypadkowym dodatkiem, nieistotnym produktem ubocznym - jak kolor kości czy ciepło silnika.

Erotyczna pasja nasycona jest intensywnymi doznaniami, niezgłębionymi emocjami, fantazją, zgodą, niebezpieczeństwem, konfliktem i przygodą każdego rodzaju ludzkiej intymności i odrębności. Powiązania między erotyką a reprodukcją są oczywiste. Estetyczne światy naturalnego i artystycznego piękna już nie łączą się w sposób tak oczywisty z reprodukcją. Jednak sztuka również może 
tworzyć wzniosłą przyjemność i ekscytację, oraz pomagać nam w zrozumieniu ludzkich możliwości. Estetyka, podobnie jak erotyka, powstaje spontanicznie jako źródło przyjemności w kulturze na całym świecie, co oznacza, że nie bez przyczyny darwiniści nie powinni jej ignorować. Biorąc pod uwagę jej ewidentną uniwersalność, przyjemność z niej płynąca powinna być równie łatwa do wytłumaczenia, jak przyjemność płynąca z seksu czy jedzenia; to, że nie jest, stanowi główny problem dla każdego, kto chciałby rozszerzać znaczenie ewolucji w odniesieniu do całości ludzkiego doświadczenia.

W innym miejscu pokazałem (Dutton, 2009, rozdz. 1), jak wrodzone interesy i emocjonalne reakcje na naturalne krajobrazy kolidują z gustami wielu ludzi, którzy uważali, że nie prowadzą bogatego życia kulturalnego. Plejstoceńskie dziedzictwo wpływa na malarstwo krajobrazowe (tzw. landszafty), wygląd kalendarzy oraz projekty parków czy pól golfowych. Niewłaściwe jest jednak odnoszenie tych nowoczesnych zjawisk do produktów ubocznych prehistorycznych impulsów czy emocji: nawiązują one raczej bezpośrednio do pradawnych i trwałych zainteresowań i tęsknot. Pinker słusznie powątpiewa w próby nadawania ważności sztuce, aby wydawała się ona jeszcze głębsza i ważniejsza, poprzez wymyślanie jej adaptacyjnych historii. Jednak w tym przypadku nie jest wymagane żadne dodatkowe uzasadnienie; zadanie, jakie stawiają sobie estetycy ewolucyjni, jest następujące: zastosować inżynierię odwrotną do badania naszych dzisiejszych gustów - zaczynając od tych, które pojawiają się spontanicznie i uniwersalnie w celu zrozumienia, skąd pochodzą. Jest to uzasadnione działanie, ponieważ doświadczamy dziś sztuki w podobny sposób jak seksu czy jedzenia.

Przykładami przyjemności obmyślonych jako produkty uboczne, do których Pinker odnosił się wielokrotnie, są substancje chemiczne, które spożywamy w celu pobudzenia obwodów w mózgu odpowiedzialnych za odczuwanie przyjemności. Opisuje on rekreacyjne narkotyki jak analogię klucza otwierającego skróty prowadzące do centrów przyjemności: dają nam przyjemność bez trudu, który musielibyśmy podjąć, aby osiągnąć taki sam stan w sposób naturalny. W tym przypadku możemy się zgodzić, że termin produkt uboczny jest tu właściwy. Gdyby chemicy wynaleźli pigułki, które dostarczyłyby nam uczucia przyjemności, jakie towarzyszy nam podczas zdobywaniu górskiego szczytu, bez podejmowania wysiłku wspinaczki, wydaje mi się, że wiele osób skorzystałoby z takiego farmakologicznego skrótu. Jednak nie istniałby naturalny związek między emocjami, które możemy odczuwać, stojąc na szczycie góry, wspinając się na nią, i emocją, którą odczuwalibyśmy po zażyciu tabletki. 
Emocjonalnie poruszające malowidło przedstawiające krajobraz nie może jednak wpływać na nas w ten sam sposób. Połączenie uczuć towarzyszących oglądaniu krajobrazu Salvatora Rosa i naszych plejstoceńskich preferencji krajobrazowych nie jest relacją uboczną (by-product relation). Rosa malował swoje obrazy dokładnie w celu wywołania takich odczuć: związek jest zatem naturalny. Obraz nie jest pigułką, która wpływa na nasz mózg chemicznie a jednak daje nam „piękny krajobraz” i odczucia z nim związane. Pinker wspomina o tym, gdy tłumaczy, że sztuka może być postrzegana jako sposób na to, aby: „dotrzeć do obwodów przyjemności w mózgu, żeby dostarczył małych impulsów uciechy, bez niewygody wydzierania bona fide przyrostu od surowego świata" (Pinker, 2002: 566). Faktycznie, malowidło w pewnym sensie może być obmyślone jako udogodnienie. „Pojedźmy na wieś i popodziwiajmy widoki.” „Nie. To potrwa zbyt długo. Wolałbym, abyśmy zamiast tego usiedli i pooglądali jakieś ładne zdjęcia krajobrazów." Ale to nie jest produkt uboczny.

Moje argumenty zostały poparte założeniem, że słownik adaptacji kontra produktów ubocznych nie może oddać sensu pradawnemu pochodzeniu i dzisiejszym realiom doświadczeń estetycznych i artystycznych. Aby wyjaśnić sztukę przez ewolucję, nie zawsze trzeba ją wychwalać jako darwinowską adaptację, podobną do języka, widzenia obuocznego czy samego oka. Sztuka nie powinna być również sprowadzana do produktu ubocznego połączenia ludzkiej biologii i kultury. Sztuka intensyfikuje doświadczenia, zwiększa je, rozciąga w czasie i spaja ze sobą. Nawet zastępując ją czymś innym, nie da się osiągnąć takiego momentu przyjemności, jaki dostarcza nam sztuka. W 1973 roku w filmie Śpioch Woody Allen ukazuje przyszłość: ludzie wchodzą do specjalnego urządzenia nazwanego „orgazmatronem”, w którym otrzymują natychmiastowo pożądane uczucie przyjemności seksualnej, bez wszystkich męczących i czasochłonnych czynności wstępnych (najciekawszy moment dla widza zaczynał się w momencie, w którym Woody przypadkowo został zatrzaśnięty w orgazmatronie). Artystycznym odpowiednikiem powinien być tu „estetykotron”. Wejdź do niego, naciśnij odpowiedni przycisk i odczuj miłe doświadczenia związane z Rozważna i romantycznq czy Łucja z Lammermooru bez konieczności czytania książki czy siedzenia w operze. Tym, co sprawia, że ten żart jest śmieszny (o ile jest), jest absurdalność próby wyobrażenia sobie, że istnieje jakiś konkretny stan umysłu, jak w przypadku orgazmu, który jest wywoływany przez sztukę. W każdym wspaniałym dziele sztuki, jak we wspinaczce górskiej, chodzi o wywoływanie pewnego specjalnego procesu doświadczania go - i nie chodzi tu o wywołanie 
jakiejś chwilowej przyjemności, która wynika $\mathrm{z}$ doświadczania go. W takim przypadku tabletki rzeczywiście mogłyby okazać się skuteczne.

Posiłkując się mniej zabawną, lecz z pewnością nie mniej uroczą analogią zaczerpniętą od niemieckiego estetyka Eckarta Volanda, pomyślmy o ćmie krążącej w nocy wokół latarni. W odniesieniu do sztuki powinniśmy być może postrzegać się jako ćmy, które „wynalazły latarnię w celu czerpania przyjemności z kręcenia się wokół niej" (Voland, 2011: 320) Jeśli sztuka jest latarnią, to darwinowskie pytanie brzmi: dlaczego tak ciężko pracowaliśmy, żeby ją wynaleźć i dlaczego taką przyjemność sprawia nam kręcenie się wokół niej. Wyewoluowane adaptacje istnieją po to, aby je odkrywać, podobnie jak ich rozszerzenia w naszym artystycznym i estetycznym życiu.

Thum. Jerzy Luty

\section{Literatura}

Dutton D. (2009). The Art Instinct. Beauty, Pleasure and Human Evolution. New York.

Gould S.J. (1997). Evolution: The Pleasures of Pluralism. New York Review of Books, June 26.

Gould S.J., Lewontin R.C. (2011). Pendentywy w katedrze św. Marka a paradygmat Panglossa. Krytyka programu adaptacyjnego, przeł. K. Bielecka. „Przegląd Filozoficzno-Literacki”, nr $2 / 3(31)$, s. $63-85$.

Lloyd E. (2005). The Case of the Female Orgasm: Bias in the Science of Evolution. Cambridge.

Pinker S. (2005). Tabula rasa. Spory o naturę ludzka, przeł. A. Nowak. Gdańsk.

Pinker S. (2005a), Forward. [W:] The Handbook of Evolutionary Psychology. Ed. by D. Buss. New Jersey.

Pinker S. (2002). Jak dziata umyst, przeł. M. Koraszewska. Warszawa.

Symons D. (1979). The Evolution of the Human Sexuality. New York.

Voland E. (2011). Preferencje estetyczne w świecie artefaktów-przystosowanie do osqdu „uczciwych sygnalów”, przeł. J. Luty. „Przegląd Filozoficzno-Literacki”, nr 2/3(31), s. 299-323.

Wilson E.O. (2002). Konsiliencja. Jedność wiedzy, przeł. J. Mikos. Poznań. 